\title{
Permanent Tooth
}

National Cancer Institute

\section{Source}

National Cancer Institute. Permanent Tooth. NCI Thesaurus. Code C33313.

Any of the 32 teeth that replace the deciduous teeth of early childhood. 